\title{
MORPHOLOGY VARIATION OF METARHIZIUM ANISOPLIAE FROM SOIL IN NORTH SUMATRA AREAS
}

\author{
Desianty Dona Normalisa Sirait ${ }^{1 *}$, Maryani Cyccu Tobing ${ }^{2}$, Irda Safni ${ }^{2}$ \\ ${ }^{1}$ Post Graduate of Agrotechnology, Agriculture Faculty, University of North Sumatra, Medan, Indonesia \\ ${ }^{2}$ Agrotechnology Department, Agriculture Faculty, University of North Sumatra, Medan, Indonesia \\ *Corresponding Author: desianty dns@yahoo.com
}

\begin{abstract}
Metarhizium anisopliae is an important entomopathogenic fungus that mainly used for biological control. Isolates of M. anisopliae extracted from soil from 15 oil palm plantations located in several districts on the Province of North Sumatra, Indonesia have been investigated to identify their morphological diversity. The morphology of assessed fungi was constructed in the the form of conidia, conidia size, color and shape colony and growth diameter of the 15 isolates. All of conidia forms showed cylindrical shape and string together. The length/width $(\mu \mathrm{m})$ ratio of conidia size was minimum 2,16 and maximum 3,54. The highest growth rate isolates were found in M3 (Bandar Selamat) and M12 (Mancang) treatment and the lowest rate was M11 (Teluk Parit Kaca) treatment. The color of colonies were varied among the isolates. They were greenish yellow, dark green, yellowish and showing zonation/no zonation.
\end{abstract}

Keywords : Metarhizium anisopliae, biological character, morphological diversity

\section{INTRODUCTION}

Currently, the development of several biological controls as one of the benefits of integrated pest management is increasing. This is done to reduce or eliminate the use of chemical pesticides, both on agricultural land and forestry, so that the impact is less to human health and the environment (Sapna Bai et al., 2015). The entomopathogenic fungi, M. anisopliae, was discovered by Sorokin in 1883, has a wide range of hosts. This fungus is widely used as a biological agent throughout the world, mainly as an inundation control (Hoe et al., 2009; Zimmermann, 2007).

Microbial control is an aspect of biological insect control and consists of the rational use of pathogens to maintain pest balances in agricultural environments, with increaes in the numbers of other natural enemies often being observed in fields where microbial control has been used (Tiago et al., 2014). Metarhizium is wide spread in nature and is found in soil, at the rhizosphere of plants or athropod cadavers as saprophyte and parasitizes a broad range of insect. Metharizium grows vegetatively as hyphae producing mycelia and conidia that are the infective propagules on arthropods host and culture media. Although the overal host range of M. anisopliae is broad, individual strains can target only particular hosts (Schrank et al., 2010). The aim of this study was to establish the level of diversity among several isolates of $M$. anisopliae, isolated from various locations of oil palm plantations.

\section{MATERIALS AND METHODS.}

\subsection{Isolation of M. Anisopliae from Soil Samples of Several Districts}

M. anisopliae was obtained from the isolation of soil samples obtained from the palm oil plantation from 5 (five) districts of North Sumatra province where samples from each district were taken from 3 (three) subdistricts and each district was taken 1 (one) village. Soil samples were taken around the roots of the plant by using a small shovel at a depth of 10-15. Then put in a plastic bag and labeled according to the sampling location and time. The soil sample is taken to the laboratory and stirred until it is flat (composited). Isolation of $M$. anisopliae was performed by modifying the larvae T. molitor trap method proposed by Trizelia et al. (2011) and Inglis et al. (2012). The trap method by inserting $300 \mathrm{~g}$ into a plastic container and putting 10 larvae of T. molitor. Then incubated at room temperature $\left(28^{\circ} \mathrm{C}\right)$ for $10-14$ days. Dead larvae that have symptoms of $M$. anisopliae disease were taken and sterilized the surfaces with $1 \%$ sodium hypochlorite and rinsed twice with sterile water and dried. Isolation of larvae by cutting larvae of larvae and taking part in the larvae body and inoculated onto sterile SDAY medium (Inglis $e t$ al., 2012) in petri dishes. M. anisopliae cultures waere taken with a $5 \mathrm{~mm}$ cork drill, then implanted on SDAY medium and incubated for 16 days at $28^{\circ} \mathrm{C}$.

\subsection{Experimental design}

The method used in this research is Completely Randomized Design (RAL) non factorial with 15 treatment of three replications. The treatment was conducted in locations as follow:

M1 = village Kampung Baru, sub district of Bilah Barat in Labuhan Batu district 
M2 = village Bandar Rejo, sub district of Rantau Selatan in Labuhan Batu district

M3 = village Bandar Selamat, sub district of Rantau Utara in Labuhan Batu district

M4 = village Sipenggeng, sub district of Batang Toru in Tapanuli Selatan district

M5 = village Perdamean, sub district of Muara Batang Toru in Tapanuli Selatan district

M6 = village Bandar Tarutung, sub district of Angkola Sangkunur in Tapanuli Selatan district .

M7 = village Lanbau, sub district of Bandar in Simalungun district

M8 = village Bandar Tonga, sub district of Bandar Huluan in Simalungun district

M9 = village Lias Baru, sub district of Bandar Masilam in Simalungun district

M10 = village Perdamaian, sub district of Binjai in Langkat district

M11 = village Teluk Parit Kaca, sub district of Secanggang in Langkat district

M12 = village Mancang, sub district of Selesai in Langkat district

M13 = village Gunung Rintih, sub district of STM Hilir in Deli Serdang district

M14 = village Namotualang, sub district of Sibiru-biru in Deli Serdang district

M15 = village Kutambelin, sub district of Pancur in Deli Serdang district

\section{RESULT AND DISCUSSION}

Identification of M. anisoplae was observed by seeing the colony morphology, size, shape and conidia. Morphological of conidia in SDAY under bright field microscope are cylindrical shape with round end and commonly light green in color and string together (Fig. 1). The fifteen isolates of this study, were identified as $M$. anisopliae. The conidial size with minimum and maximal width is respectively $1.81 \mu \mathrm{m}$ and $2.76 \mu \mathrm{m}$, and the minimum and maximum length is respectively $5,96 \mu \mathrm{m}$ and $6,54 \mu \mathrm{m}$. This is consistent with research conducted by Ghayedi and Abdollahi (2013) that conidia M. anisopliae is cylindrical to oval and measuring $<9 \mu \mathrm{m}$. Ratio length/width of conidia size was minimum 2,16 and maximum 3,54. This similar to Tangthirasunun et al. (2010) who reported conidia dimension of $M$. anisopliae. They grouped the length/width ratio into 3 groups. Low ratio length/width group of conidia is $\leq 2.18$, medium ratio length/width group of conidia is between 2.33 and 2.87 and hight ratio length/width group of conidia is $\geq 2.91$.

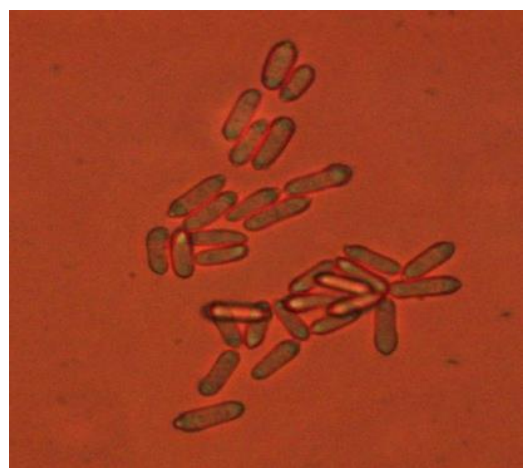

Fig. 1. The morphology of conidia under bright field light microscope (100x) with lactophenol blue staining.

The colony color differ the growth of colony was observed on SDAY at $28^{\circ} \mathrm{C}$ for 16 days. Fungal micelium are initially white or cream. Becoming shades of yellow, shades of green/yellow to shade of dark during sporulation. Most isolates are greenish yellow and yellowish, except M13 is dark green (Fig. 1). For the results of observation color colony aged 16 days, it can be seen in general colonies are white to greenish yellow to dark green. This is the same as the research conducted by Ghayedi and Abdollahi (2013) that the colony of M. anisopliae is yellowish green or olive green. M. anisopliae has been described as having yellowish green, olivaceous, dark-herbage gree, pink or vinaceous buff (Bridge et al., 1993). Sapna Bai et al., (2015) also reported the morphology of colony color M. anisopliae are pale green and dark green.

Table 1. Size of conidia and colony color of isolate $M$. anisopliae

\begin{tabular}{|c|c|c|c|c|c|}
\hline \multirow[t]{2}{*}{ Isolate } & \multirow[t]{2}{*}{ Host } & \multirow[t]{2}{*}{ Origin } & \multicolumn{2}{|c|}{$\begin{array}{l}\text { Average size of } \\
\text { Konidia }(\mu \mathrm{m})\end{array}$} & \multirow[t]{2}{*}{ Colony color } \\
\hline & & & Width & Length & \\
\hline 1 & Soil & Kampung Baru, Labuhan Batu & 2.31 & 6.23 & Greenish yellow \\
\hline 2 & Soil & Bandar Rejo, Labuhan Batu & 2.10 & 6.06 & Greenish yellow \\
\hline 3 & Soil & Bandar Selamat, Labuhan Batu & 1.87 & 5.98 & Greenish yellow \\
\hline 4 & Soil & Sipenggeng Tapanuli Selatan & 1.93 & 6.26 & Greenish yellow, with zonation \\
\hline 5 & Soil & Perdamean Tapanuli Selatan & 2.21 & 6.02 & Greenish yellow \\
\hline
\end{tabular}




\begin{tabular}{llllll}
6 & Soil & Bandar Tarutung Tapanuli Selatan & 2.22 & 6.25 & Greenish yellow, with zonation \\
7 & Soil & Lanbau Simalungun & 2.33 & 6.48 & Greenish yellow, with zonation \\
8 & Soil & Bandar Tonga Simalungun & 2.43 & 6.41 & Greenish yellow \\
9 & Soil & Lias Baru Simalungun & 2.01 & 6.54 & Greenish yellow \\
10 & Soil & Perdamaian Langkat & 1.94 & 6.16 & Greenish yellow, with zonation \\
11 & Soil & Teluk Parit KacaLangkat & 1.95 & 6.22 & Greenish yellow \\
12 & Soil & Mancang Langkat & 1.81 & 6.40 & Greenish yellow \\
13 & Soil & Gunung Rintih Deli Serdang & 2.01 & 6.38 & Dark green, with zonation \\
14 & Soil & Namotualang Deli Serdang & 2.76 & 5.96 & Yellowish \\
15 & Soil & Kutambelin Deli Serdang & 2.31 & 6.47 & Greenish yellow \\
\hline
\end{tabular}
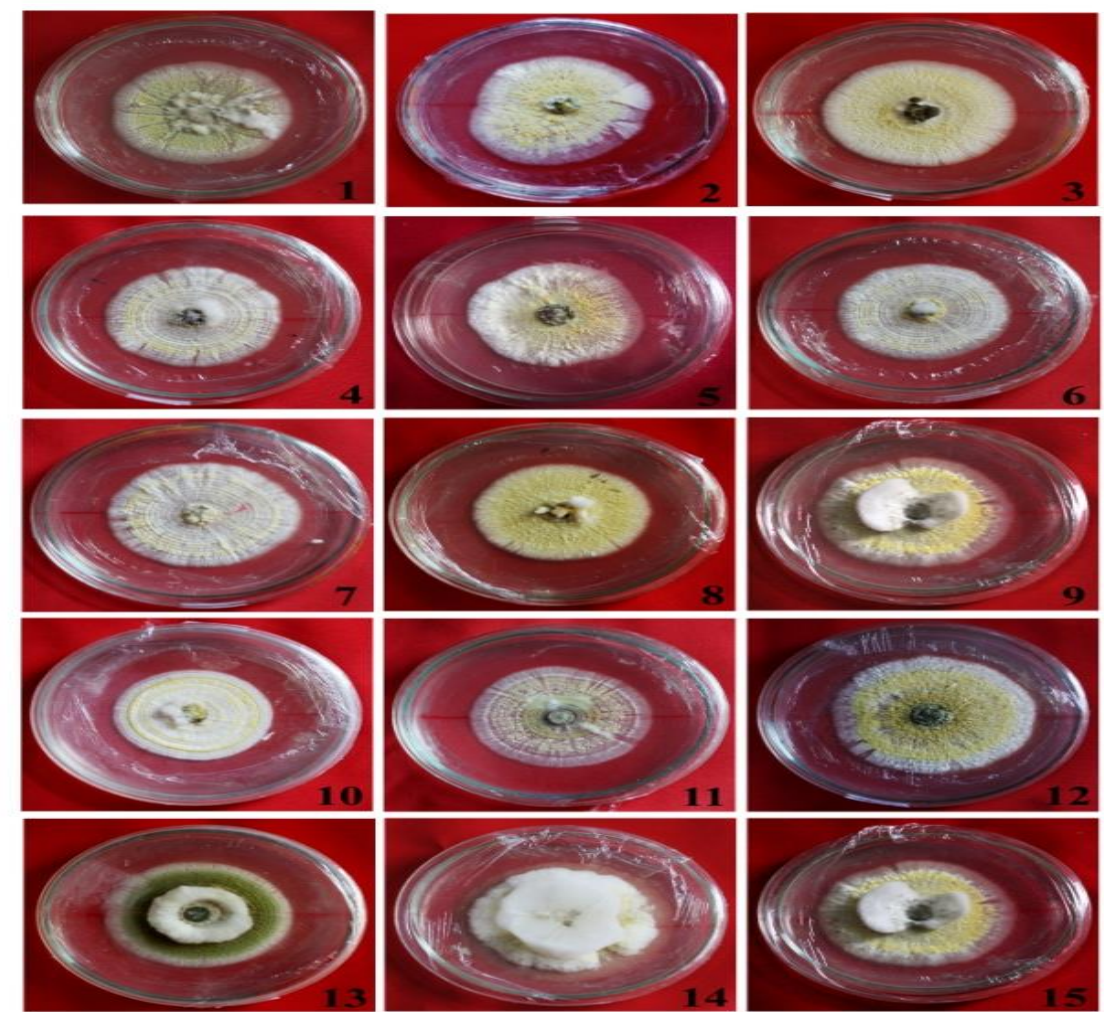

Fig. 2. Metarhizium anisopliae originated: 1. Kampung Baru (Labuhan Batu) 2. Bandar Rejo (Labuhan Batu), 3. Bandar Selamat (Labuhan Batu), 4 Sipenggeng (Tapanuli Selatan), 5. Perdamean (Tapanuli Selatan), 6. Bandar Tarutung (Tapanuli Selatan), 7. Lanbau (Simalungun), 8. Bandar Tonga (Simalungun), 9. Lias Baru (Simalungun), 10. Perdamaian (Langkat), 11. Teluk Parit Kaca (Langkat), 12. Mancang (Langkat), 13. Gunung Rintih (Deli Serdang), 14. Namotualang (Deli Serdang), Kutambelin (Deli Serdang).

Tabel 2. Growth diameter M. anisopliae at 1st until 16th day Growth diameter M. anisopliae at 1 st until 16th day

\begin{tabular}{|c|c|c|c|c|c|c|c|c|c|c|c|c|c|c|c|c|}
\hline \multirow{2}{*}{ Treatment } & \multicolumn{13}{|c|}{ Growth diameter M. anisopliae at 1 st until 16th day } & \multirow[b]{2}{*}{14} & \multirow[b]{2}{*}{15} & \multirow[b]{2}{*}{16} \\
\hline & 1 & 2 & 3 & 4 & 5 & 6 & 7 & 8 & 9 & 10 & 11 & 12 & 13 & & & \\
\hline M1 & 7,33 & 7,83 & 9,67 & 12,17 & 15,00 & 17,33 & 20,33 & 22,83 & 25,33 & 27,83 & 30,00 & 33,33 & 36,67 & 39,33 & 41,50 & $\begin{array}{l}44,67 \\
\text { de }\end{array}$ \\
\hline M2 & 7,00 & 9,33 & 11,00 & 13,00 & 17,33 & 19,67 & 23,17 & 25,33 & 30,50 & 31,17 & 34,33 & 37,33 & 40,33 & 47,17 & 49,17 & \\
\hline M3 & 9,00 & 11,67 & 15,67 & 19,33 & 23,67 & 26,33 & 33,33 & 38,33 & 37,00 & 40,50 & 51,50 & 54,17 & 57,67 & 65,33 & 66,00 & $\begin{array}{l}69,33 \\
\text { a }\end{array}$ \\
\hline M4 & 7,17 & 8,50 & 10,67 & 14,50 & 16,67 & 21,33 & 23,00 & 26,33 & 29,17 & 32,67 & 35,17 & 38,33 & 41,83 & 44,67 & 47,50 & \\
\hline M5 & 7,67 & 8,67 & 10,00 & 12,50 & 16,50 & 19,50 & 21,50 & 25,17 & 27,50 & 31,17 & 34,67 & 36,17 & 38,50 & 43,83 & 46,67 & $\begin{array}{l}50,35 \\
\text { bcd }\end{array}$ \\
\hline
\end{tabular}




\begin{tabular}{|c|c|c|c|c|c|c|c|c|c|c|c|c|c|c|c|c|}
\hline M6 & 7,00 & 9,50 & 11,00 & 15,00 & 17,67 & 21,00 & 23,33 & 26,67 & 29,50 & 31,00 & 32,67 & 35,67 & 42,33 & 46,00 & 48,50 & $\begin{array}{l}51,83 \\
\text { bcd }\end{array}$ \\
\hline M7 & 7,00 & 9,50 & 10,50 & 15,00 & 17,17 & 21,33 & 24,33 & 27,17 & 31,50 & 35,17 & 37,33 & 41,33 & 44,17 & 46,83 & 50,17 & $\begin{array}{l}53,33 \\
b\end{array}$ \\
\hline M8 & 7,83 & 9,33 & 11,50 & 15,17 & 16,50 & 18,67 & 21,83 & 24,17 & 27,00 & 29,17 & 33,00 & 38,00 & 41,67 & 43,83 & 46,67 & $\begin{array}{l}48,83 \\
\text { bcd }\end{array}$ \\
\hline M9 & 7,67 & 9,83 & 10,83 & 13,00 & 15,17 & 17,17 & 21,00 & 24,17 & 26,83 & 29,33 & 31,33 & 34,00 & 37,33 & 40,00 & 42,67 & $\begin{array}{l}46 \\
\text { bcde }\end{array}$ \\
\hline M10 & 7,00 & 9,17 & 11,33 & 14,67 & 17,17 & 21,50 & 23,00 & 26,50 & 30,17 & 33,17 & 35,50 & 37,33 & 39,00 & 43,00 & 46,00 & $\begin{array}{l}48,17 \\
\text { bcde }\end{array}$ \\
\hline M11 & 7,67 & 8,00 & 9,50 & 11,83 & 14,50 & 16,17 & 18,83 & 21,17 & 24,00 & 25,50 & 27,50 & 30,83 & 34,33 & 36,33 & 38,50 & $\begin{array}{l}40,5 \\
\mathrm{e}\end{array}$ \\
\hline M12 & 8,83 & 9,67 & 13,50 & 17,00 & 21,00 & 24,67 & 27,17 & 31,00 & 34,83 & 40,17 & 45,17 & 47,17 & 51,50 & 54,17 & 58,83 & $63 \mathrm{a}$ \\
\hline M13 & 8,17 & 10,33 & 12,67 & 13,67 & 16,17 & 18,00 & 23,00 & 25,00 & 28,33 & 30,17 & 34,17 & 36,50 & 38,17 & 40,00 & 44,00 & $\begin{array}{l}47,33 \\
\text { bcde } \\
45,33\end{array}$ \\
\hline M14 & 8,17 & 9,67 & 10,33 & 13,17 & 15,50 & 17,50 & 20,00 & 22,33 & 25,00 & 28,17 & 31,33 & 34,50 & 36,83 & 40,67 & 43,50 & $\begin{array}{l}\text { cde } \\
50,5\end{array}$ \\
\hline M15 & 8,33 & 9,50 & 10,67 & 14,67 & 18,17 & 21,33 & 24,17 & 26,00 & 30,00 & 32,50 & 35,67 & 38,00 & 41,17 & 43,33 & 47,67 & bcd \\
\hline
\end{tabular}

In the Tabel 2. showed M3 (Bandar Selamat) and M12 (Mancang) are faster growth than other isolates. Then among M6, M4, M15, M5, M8, M10, M13 and M9 is significantly different from M14, M1 and M11. In nature isolates of M. anisopliae contain diverse assemblage of genotypes and probably comprise species complexes. Therefore, it is not surprising that within the isolates, individual isolate can show variation biological characters (Rachappa et al., 2009). Milner et al. (2002) founded ariation in colony characters of M. anisopliae collected from geographical locations and host insects.

\section{CONCLUSION}

M. aniospliae has a morphological diversity from the shape and color of colonies, conidia size and diameter growth. But for the level of virulence to the insects, it is necessary to obtain a virulent isolate that can be used for biological control. It is also recommended that molecular testing be conducted to see the genetic diversity.

\section{REFERENCES}

Bridge, P.D., Williams, M.A.J., Prior, C. And Paterson, R.R.M. 1993. Morphological, biochemical and molecular characteristics of Metahrizium anisopliae ad M. flavoridae. J. Gen. Microbiol. 139: 1163-1169.

Ghayedi, S. and Abdollahi, M. 2013. Biocontrol potential of Metarhizium anisopliae (Hypocreales: Clavicipitaceae), isolated from suppressive soils of the Boyer-Ahmad region, Iran, against J2S of Heterodera avenae. Pl. Prot. Res. 53(2): 165-171.

Hoe, P.K., Bong, C.F.J., Jugah, K. And Rajan, A. 2009. Evaluation of Metarhizium anisopliase var. anisopliae (Deuteromycotina: Hyphomycete) isolates and their effects on subterranean termite Coptotermes curvignathus (Isoptera: Rhinotermitidae). American J. Agric. Biol. Sci. 4(4): 289-297.

Inglis, G.D., Enkerli, J. and Goettel, M.S. 2012. Laboratory techniques used for entomopathogenic fungi: Hypocreales. In: Manual of Techniques in Invertebrate Pathology, Second Edition ed. Lacey, L.A. Academic Press, Great Britain, pp. 189-253.

Samuels, R.I., Coracini, D.L.A., Martins, C.A., dos Santos, M. and Gava, C.A.T. 2002. Infection of Blissus antillus (Hemiptera; Lygaeidae) Eggs by the Entomopathogenic Fungi Metarhizium anisopliae and Beauveria bassiana. Biological Control. 23: 269-273.

Sapna Bai, N., Sasidharan, T.O., Remadevi, O.K. and Dharmarajan, P. 2015. Morphology and RAPD analysis of certain potentially entomopathogenic isolates of Metarhizium anisopliae Metsch. (Deuteromycotina: Hypocreales). Microbiol. Biotechnol. Res. 5(1): 34-40.

Schrank, A. and Vainstein, M.H. 2010. Metarhizium anisopliae enzymes and toxins. Toxicon. 56: 1267-1274.

Tangthirasunun, N, Poeaim, S., Soytong, K., Sommartya, P and Popoonsak, S. 2010. Variation in morphology and ribosomal DNA among isolates ofMetarhizium anisopliae from Thailand. J. of Agr. Tech. 6(2): 317-329.

Tiago, P.V., de Oliveira, N.T. and de Luna Alves Lima, E.A. 2014. Biological insect control using Metarhizium anisopliae: morphological, molecular, and ecological aspects. Ciencia Rural. 44(4): 645-651.

Zimmerman, G. 2007. Review on safety of the entomopathogenic fungus Metarhizium anisopliae. Biocont. Sc. Tech. 17(9): 879-920. 